\title{
Gençlik Merkezi Faaliyetlerine Katılan Suriyeli Mültecilerin Algıladıkları Hizmet Kalitesi Üzerine Bir Araştırma
}

\author{
Arif ÖZSARI ${ }^{1,2}$, İ. Bülent FişEKÇIOĞLU ${ }^{3}$, Mehmet ALTIN ${ }^{3}$ \\ ${ }^{2}$ Osmaniye Gençlik Hizmetleri ve Spor Il Müdürlüğ̈̈ \\ ${ }^{3}$ Selçuk Üniversitesi, Spor Bilimleri Fakültesi
}

Öz

Bu çalışmanın amacı, Gençlik Merkezi faaliyetlerine katılan Suriyeli Mültecilerin algıladıkları hizmet kalitesinin fiziksel çevre, etkileşim ve çıktı kaliteleri bakımından incelenmesidir. Araştırmanın evrenini Osmaniye gençlik merkezindeki Suriyeli mülteciler, örneklemi ise Osmaniye gençlik merkezi kültürel, sportif ve sosyal faaliyetlere katılan 106 erkek, 63 kadın olmak üzere toplamda gönüllü 169 Suriyeli mülteci oluşturmaktadır. Verilerin toplanmasında kişisel bilgilerin yer aldığı demografik form ile Aycan (2005) tarafından gençlik merkezlerine yönelik olarak geliştirilen, daha sonra Polat ve ark., (2013) tarafindan yeniden düzenlenerek geçerlik ve güvenilirlik çalışması yapılan "Gençlik Merkezlerinde Algılanan Hizmet Kalitesi Ölçeği" kullanılmıştır. $\mathrm{Bu}$ çalışma için, verilerin homojenliği ve varyansları test edilmiş, farkl11ıkların belirlenmesinde Independent-Samples $\mathrm{T}$ Testi, One-Way ANOVA, farklılığın kaynağının tespit edilmesinde ise Tukey testi kullanılmıştır. Ölçeğin bu çalışma için hesaplanan Cronbach Alpha değeri ,82 olarak tespit edilmiştir. Algılanan hizmet kalitesi ölçeğinin tüm soruları için Suriyeli mültecilere ait ortalama değer 4,33 \pm 0,47 olarak tespit edilmiştir. Mültecilerin barınma ve medeni durum faktörlerine bağlı olarak algıladıkları hizmet kalitesi boyutlarında istatistiksel açıdan anlamlı bir farklılığa rastlanmazken; cinsiyete bağlı olarak hizmet kalitesi alt boyutlarının tamamında kadınlara ait değerler, erkeklere nazaran yüksek bulunmuş ve bu değişimin istatistiksel açıdan da anlamlı olduğu belirlenmiştir $(\mathrm{p}<0.05)$. Suriyeli mültecilerin tesis kullanımı, gelir ve etkinlik türü faktörlerine bağlı olarak algıladıkları hizmet kalitesi boyutlarında istatistiksel açıdan anlamlı bir farklılığa rastlanmamıştır. Yaş faktörüne bağlı algılanan hizmet kalitesi alt boyutlarında fiziksel çevre kalitesi ve çıktı kalitesi alt boyutlarında; eğitim faktörüne bağlı olarak ise tüm algılanan hizmet kalitesi boyutlarında istatistiksel anlamda farklılıklar gözlenmiştir $(\mathrm{p}<0.05)$. Araştırmamız bulgularına dayanarak Suriyeli mültecilerin genel anlamda algıladıkları hizmet kalitesinden memnun oldukları söylenilebilir.
Orijinal Makale

Gönderi Tarihi: 16.05 .2017

Kabul Tarihi: 11.06.2017

Online Yayın Tarihi: 16.06.2017

DOI: $10.25307 /$ jssr.313871

\footnotetext{
${ }^{1}$ Sorumlu Yazar:

E-mail: arifozsari@hotmail.com, Tel: +905358268843
}

\author{
Anahtar kelimeler: \\ Hizmet kalitesi, \\ Gençlik Merkezleri, \\ Suriyeli Mülteciler.
}




\section{A Research on the Service Quality Perception of the Syrian Refugees Took Part in the Youth Center Activities}

\begin{tabular}{lr} 
Abstract & Original Article \\
\hline The aim of the paper is to study the quality of service perceived by the Syrian Refugees & Article Info \\
who take part in the activities of the youth centre in view of the physical environment, inter & Received: 16.05 .2017 \\
reaction and output quality. The universe of the research is the Syrian Refugees at the youth & 11.06 .2017 \\
centre in Osmaniye. The sample contains 106 male and 63 female volunteer Syrian & Online Published: 16.06.2017 \\
refugees who participate in the cultural, sportive and social activities at the youth centre. & For gathering the data, the demographic form in which the personal data are kept and 'The \\
Scale of the Service Quality Perceieved at the Youth Centres', which was developed by & DOI: 10.25307/jssr.313871 \\
Aycan (2005) for the youth centres, and then rearanged and revised for validity and \\
reliability by Polat and his frends (2013), were used. For this study, the homogeneity and \\
variations of the data were tested; Independent-Samples T Test, One Way Anova for \\
detecting "difference', the Test of Tukey for detecting the source of difference were used. \\
Cronbach Alpha value of the scale for this study was found ,82. The avarage value of \\
'Scale of Service Quality Perceived' for all the questions to the Syrian refugees was found \\
$\begin{array}{l}4,33 \pm 0,47 . \text { A meaningful difference was not found on the dimension of service quality in } \\
\text { view of accomodation and marital status. Depending on sex, the values of the females of all } \\
\text { sub-dimensions in service quality are higher than those of males. The difference is } \\
\text { meaningful on the statistical scale (p<0.05). A meaningful difference was not found in the } \\
\text { dimensions of facility use by the Syrian refugees, the service quality perceived depending } \\
\text { on income and type of event. There is a meaningful difference in the sub-dimensions of } \\
\text { 'Service Quality Perceived', physical facility quality and output quality. In the sub- } \\
\text { dimensions of Service Quality Perceived depending on age it was found statistical } \\
\text { differences in all service quality perceived (p<0,05). Based on our research findings, it can } \\
\text { be said that the Syrian Refugees are generally pleased with the quality of services they get. }\end{array}$ \\
\hline
\end{tabular}

\section{Gİiș}

Kalite; evrensel, kültürel, sosyal ve kişisel bir dizi seviyeye sahiptir. Kısaca, kalite kusurlardan arındırılmış ürünler olarak tanımlanabilir (Tjiptono \& Chandra, 2005). Hizmet kalitesi kavramı, algısal kaliteye dayanır; algısal kalite ise tüketicinin bir varlığın genel mükemmellik ve üstünlüğüne ilişkin yargısı olarak ifade edilir (Parasuraman ve ark., 1985). Algılanan hizmet, beklenen hizmetin altına düştüğünde, müşteriler o hizmet organizasyonuna ilgilerini kaybederler. Aynı şekilde eğer algılanan hizmet müşterilerin beklentilerini karşılar veya aşarsa, o organizasyonun hizmetlerini tekrar kullanırlar (Kotler, 2002). Hizmetler soyut nitelikte olduğundan, soyut niteliklere sahip olan hizmetin kalitesi de soyut bir yapıya sahiptir. Bu nedenle hizmet kalitesi kavramı yerine "algılanan hizmet kalitesi”" kavramı kullanılmaktadır (Uyguç, 1998). Parasuraman ve ark., (1985) algılanan hizmet kalitesini "müşterinin beklentileri ve algıları arasındaki farkın yönü ve derecesi" olarak tanımlamaktadırlar. Hizmet algısı beklentilere bağlı olarak değişiklik göstermektedir. Hizmetin kaliteli olarak verileceğine ilişkin beklentimiz yüksekse ve umduğumuzdan daha düşük düzeyde bir hizmet ile karşılaşmışsak, verilen hizmet başkaları için ne kadar güzel olsa da bizim için kötüdür. Bu durumun tam tersinde ise beklediğimizden daha iyi hizmetlerle karşılaşmamız biz mutlu edecek ve tatmin olmamızı sağlayacaktır (Karahan, 2006). Müşterinin algıladığı gerçek hizmet, beklentilerine eşit ya da beklentilerinden fazla ise hizmet kalitesinin yeterli olduğu, beklentilerin altında ise yetersiz olduğu düşünülür (Winer, 2000; akt: Polat ve ark., 2013). Aynı zamanda hizmetler soyut 
nitelikte olduğu için, hizmet kalitesi de soyut bir yapıya sahip olmakta ve hizmet kalitesi ile ilgili değerlendirmeler daha çok algılamalara dayalı olarak yapılmaktadır. Bu nedenlerden dolayı, hizmet kalitesini ölçmek daha zor olabilmektedir. Hizmet kalitesi, hem üretim süreci sonucunda ortaya konulan "çıktı"yı, hemde hizmetin "sunulma biçimini”" kapsamaktadır (Zeithaml ve ark., 1996). Bu doğrultuda hizmet kalitesi kavramı, tüketici ile hizmet sağlayıcısı arasındaki etkileşim sonucu ortaya çıkmaktadır (Leisen \& Vance, 2001). Tüm bu tanımlar, tüketicilerin bir nesneyi, ancak onu yorumladıktan (algıladıktan) sonra değerlendirebileceği ve buna bağlı olarak da, hizmet kalitesini, hizmeti tükettikten sonra, algıları ile beklentilerini karşılaştırarak idrak edebileceği varsayımına dayanmaktadır (Lee ve ark., 2000; akt: Dörtyol, 2012). Hizmetlerin birtakım karakteristik özelliklerinden dolay1 tüketicilerin, hizmetleri ve hizmet kalitesini değerlendirmekte zorlanması (Altan ve Atan 2004; Atan ve ark., 2006) hizmet kalitesi yerine algılanan hizmet kalitesi ifadesinin kullanılmasını gerektirmiştir (Aracıoğlu ve ark., 2005). Zeithaml (1996) algılanan hizmet kalitesini, "müşterinin, bir ürün ya da hizmetin üstünlüğü veya mükemmelliği ile ilgili genel bir yargısı" olarak tanımlamaktadır (Robledo, 2001; Devebakan ve Aksarayl1, 2003). Ghobadian ve ark., (1994) ise, algılanan hizmet kalitesini, müşterilerin hizmet kalitesine yönelik sezgileridir şeklinde tanımlamıştır.

Alan yazında hizmet kalitesi üzerine yapılan araştırmalar; müşterilerin algıladığı hizmet kalitesinin, hizmetten bekledikleri ile kendilerine sunulan hizmet arasındaki kıyaslamadan oluştuğunu belirtmektedir (Yılmaz, 2007). Bu doğrultuda müşterilerin bekledikleri hizmet (bh), algıladıkları hizmetten(ah) yüksek olursa (bh>ah), algılanan hizmet kalitesi memnun edici olmayacaktır. Beklenen hizmetin, algılanan hizmet ile eşit olması durumunda (bh=ah) ise, algılanan kalite memnun edici olacaktır. Algılanan hizmet, beklenen hizmetten yüksek olursa (ah>bh), algılanan kalite ideal olacaktır (Aslan ve ark., 2006).

Yeni kamu işletmeciliği anlayışında kamu hizmetlerinde "kalite", "vatandaş odaklılığı" ve "memnuniyet" kavramları vurgulanmaktadır. $\mathrm{Bu}$ çerçevede, sunulan hizmetlerden vatandaşların memnuniyet düzeylerinin bilinmesi, kamu kurumlarının daha doğru hizmet politikaları geliştirip uygulamalarında yol gösterici olabilir (Gürel ve Özel, 2013; Üzüm ve ark., 2016). Türkiye'de mal veya hizmet üreten birçok sektör, hizmet kalitesi ile ilgili çalışmalara önem vermekte ve rakipleri ile aralarında farklılık oluşturmaya çalışmaktadır. Gelişen teknoloji ile birlikte insanların serbest zamanlarının artması özellikle spor alanında hizmet üreten kurumların çoğalmasını sağlamıştır. Bu kurumlardan biri olan gençlik merkezleri insanların serbest zamanlarında katılabilecekleri etkinliklerin sunulmasında önemli görevler üstlenmektedir. Gençlerin sosyal, kültürel ve sportif etkinlikler çerçevesinde serbest zamanlarını değerlendirmelerine firsat veren ve ortam hazırlayan örgütler olarak tanımlanan gençlik merkezlerinin, amaçları ve etkinlik çeşitleri incelendiğinde, gençlerin çok yönlü gelişmelerinde ve serbest zamanlarını değerlendirmelerinde önemli görevler yerine getirdikleri açıkça görülebilir (Aycan, 2005).

Göç, insanların bulundukları yerden ekonomik, sosyal, siyasal ve kültürel nedenlerden dolayı başka bir yere hareket etmelerine verilen genel bir ad, evrensel bir olay olarak tanımlanabilir (Akkaş, 2015). Uluslararası mülteci hukukunun özünü oluşturan 28 Temmuz 1951 tarihli 
Cenevre Sözleşmesi'ne göre mülteci: "1rk1, dini, milliyeti, belli bir sosyal gruba mensubiyeti veya siyasi düşünceleri nedeniyle zulüm göreceği konusunda haklı bir korku taşıyan ve bu yüzden ülkesinden ayrilan ve korkusu nedeniyle geri dönemeyen veya dönmek istemeyen kişidir (UNHCR, 2017). Türkiye, 1951 tarihli Mültecilerin Hukuki Durumuna İlişkin Cenevre Sözleşmesi'ne taraf ülkelerden biridir ve 1967 tarihli Ek Protokol'e "coğrafi sınırlama" ile taraf olmuştur. Türkiye, Ekim 2011'den itibaren, Suriyeli “misafirlerini” İçişleri Bakanlığ1 Yönetmeliği'nin 10. maddesi gereğince geçici koruma rejimine aldığını ilan etmiştir. Asgari uluslararası standartlarla uyumlu olan bu rejim, açık kapı politikası, geri dönmeye zorlamama, bireysel statü belirlemenin yapılmaması, kamplarda barınma ve diğer temel hizmetlerin sunulması gibi ilkeleri içermektedir (Öner, 2014). Türkiye'nin izlediği "açık kapı politikası" çerçevesinde, pasaportu bulunmayanlar dâhil, kabul ettiği tüm Suriyeli sığınmacılara sağladığı "geçici koruma" rejimi, uluslararası kuruluşlar tarafından uluslararası hukuka ve insani yükümlülüklere uygun olarak değerlendirilmektedir (Kap, 2014).

Osmaniye ili gençlik merkezinin kültürel, sportif ve sosyal faaliyetlerine katılan Suriyeli mültecilerin, Türk toplumuna adapte olma ve günlük hayatın içerisinde yer alarak sosyal anlamda toplumda yer bulmalarının algıladıkları hizmet kalitesi düzeyiyle doğru orantılı olduğu düşünülmektedir. $\mathrm{Bu}$ düşünceden hareketle bu araştırma, Suriyeli mültecilerin algıladıkları hizmet kalitesinin incelenmesi amacıyla yapılmıştır.

\section{MATERYAL VE METOD}

\section{Araştırmanın Modeli}

Bu çalışmada, nicel araştırma yöntemlerinden nedensel karşılaştırma modeli kullanılmıştır.

\section{Araştırma Grubu}

Araştırmanın evrenini Osmaniye gençlik merkezindeki Suriyeli mülteciler, örneklemi ise Osmaniye gençlik merkezindeki kültürel, sportif ve sosyal faaliyetlere katılan 106 erkek, 63 kadın olmak üzere toplamda gönüllü 169 Suriyeli mülteci oluşturmaktadır.

\section{Veri Toplama Aracı}

Verilerin toplanmasında kişisel bilgilerin yer aldı̆̆ kişisel bilgi formu (yaş, cinsiyet, eğitim durumu, gelir düzeyi, medeni durum) ile Aycan (2005) tarafından gençlik merkezlerine yönelik olarak geliştirilen, daha sonra Polat ve arkadaşları (2013) tarafindan yeniden düzenlenerek geçerlik ve güvenilirlik çalışması yapılan "Gençlik Merkezlerinde Algılanan Hizmet Kalitesi Ölçeği” kullanılmıştır. 23 maddeden oluşan veri toplama aracı, Fiziksel çevre kalitesi (1-10. maddeler), Etkileşim kalitesi (11 - 18. maddeler), Çıktı kalitesi (19-23. maddeler) olmak üzere toplam üç (3) alt boyuttan oluşmaktadır. Ölçme aracı 5'li likert tipi (1= tamamen katılmıyorum $-5=$ tamamen katılıorum) bir yapıya sahiptir.

\section{Verilerin Toplanması}

Araştırma sürecinde elde edilen veriler araştırmacı tarafından, Osmaniye gençlik merkezindeki kültürel, sportif ve sosyal faaliyetlere katılan Suriyeli mültecilere tercüman 
yardımıyla uygulanmıştır. Anket uygulanan grup, yerel dil ve kültürden tamamen bağımsız değildir.

\section{Verilerin Analizi}

Araştırmada kullanılan verilerin analizinde SPSS (Statistical Package For Social Scientists for Windows Release16.0) programı kullanılmıştır. Verilerin normalliği ve homojen dağılıp dağılmadığı belirlendikten sonra istatistiksel gösterimlerde aritmetik ortalama, standart sapma değerleri sunuldu. İkili karşılaştırmalarda Independent-Samples t test, çoklu karşılaştırmalarda One Way Anova, farklılığın kaynağının belirlenmesinde ise Tukey testi kullanılmıştır. Ölçeğin bu çalışma için hesaplanan Cronbach Alpha değeri ,82 olarak tespit edilmiştir. Dağılımlardan elde edilen sonuçlar tablolaştırılmış ve bulgular yorumlanmıştır. Anlamlılık düzeyi 0,05 olarak alınmıştır

\section{BULGULAR}

Araştırmanın bu bölümünde elde edilen verilerin istatistiksel analizler neticesinde ortaya çıkan bulgularına ilişsin tablo ve yorumlara yer verilmiştir.

Tablo 1: Suriyeli mültecilerin tamamına ait algılanan hizmet kalitesi değişimleri

\begin{tabular}{lccccccc}
\hline & & \multicolumn{2}{c}{ Fiziksel Çevre Kalitesi } & \multicolumn{2}{c}{ Etkileşim Kalitesi } & \multicolumn{2}{c}{ Çıktı Kalitesi } \\
& & $\mathrm{x}$ & $\mathrm{ss}$ & $\mathrm{x}$ & $\mathrm{ss}$ & $\mathrm{x}$ & $\mathrm{ss}$ \\
\cline { 3 - 8 } Suriyeli Mülteciler & 169 & 4.36 & 0.61 & 4.30 & 0.54 & 4.32 & 0.52 \\
\hline
\end{tabular}

Algılanan hizmet kalitesi ölçeğinin tüm soruları için ortalama değer $(4.33 \pm 0.47)$ olarak tespit edilmiştir.

Tablo 2: Suriyeli mültecilerin cinsiyet durum faktörüne bağlı olarak algıladıkları hizmet kalitesi.

\begin{tabular}{|c|c|c|c|c|c|c|c|c|}
\hline \multirow{2}{*}{ Cinsiyet } & \multirow{2}{*}{$\mathrm{n}$} & \multirow{2}{*}{$\%$} & \multicolumn{2}{|c|}{ Fiziksel Çevre Kalitesi } & \multicolumn{2}{|c|}{ Etkileşim Kalitesi } & \multicolumn{2}{|c|}{ Çıktı Kalitesi } \\
\hline & & & $\mathrm{x}$ & ss & $\mathrm{x}$ & ss & $\mathrm{x}$ & ss \\
\hline Erkek & 106 & 62.7 & 4.23 & 0.47 & 4.20 & 0.62 & 4.21 & 0.55 \\
\hline \multirow[t]{2}{*}{ Kadın } & 63 & 37.3 & 4.57 & 0.76 & 4.46 & 0.34 & 4.50 & 0.42 \\
\hline & & $\mathbf{p}$ & \multicolumn{2}{|c|}{$.000^{*}$} & \multicolumn{2}{|c|}{$.000^{*}$} & \multicolumn{2}{|c|}{$.000^{*}$} \\
\hline
\end{tabular}

Tablo 2 incelendiğinde, Suriyeli mültecilerin cinsiyete bağlı olarak hizmet kalitesi alt boyutlarının tamamında kadınlara ait değerler erkeklere nazaran yüksek bulunmuş ve bu değişimin istatistiksel açıdan da anlamlı olduğu belirlenmiştir $(\mathrm{p}<0.05)$. 
Tablo 3: Suriyeli mültecilerin medeni durum ve barınma durumu faktörlerine bağlı olarak algıladıkları hizmet kalitesi

\begin{tabular}{|c|c|c|c|c|c|c|c|c|c|}
\hline \multirow{5}{*}{ Medeni Durum } & \multirow{4}{*}{$\begin{array}{l}\text { Evli } \\
\text { Bekar }\end{array}$} & \multirow{2}{*}{$\mathbf{n}$} & \multirow{2}{*}{$\%$} & \multicolumn{2}{|c|}{ Fiziksel Çevre Kalitesi } & \multicolumn{2}{|c|}{ Etkileşim Kalitesi } & \multicolumn{2}{|c|}{ Çıktı Kalitesi } \\
\hline & & & & $\mathrm{x}$ & ss & $\mathrm{x}$ & ss & $\mathrm{x}$ & ss \\
\hline & & 22 & 13 & 4.42 & 0.48 & 4.44 & 0.27 & 4.47 & 0.47 \\
\hline & & 147 & 87 & 4.35 & 0.63 & 4.28 & 0.57 & 4.29 & 0.53 \\
\hline & & & $\mathbf{p}$ & \multicolumn{2}{|c|}{0.509} & \multicolumn{2}{|c|}{0.195} & \multicolumn{2}{|c|}{0.108} \\
\hline \multirow{3}{*}{ Barınma Durumu } & Misafirhane & 42 & 24.9 & 4.31 & 0.48 & 4.29 & 0.64 & 4.25 & 0.54 \\
\hline & Ev & 127 & 75.1 & 4.37 & 0.65 & 4.30 & 0.51 & 4.34 & 0.51 \\
\hline & & & $\mathbf{p}$ & \multicolumn{2}{|c|}{0.495} & \multicolumn{2}{|c|}{0.881} & \multicolumn{2}{|c|}{0.328} \\
\hline
\end{tabular}

Tablo 3'ten de anlaşılacağı gibi, Suriyeli mültecilerin barınma ve medeni durum faktörlerine bağlı olarak algıladıkları hizmet kalitesi boyutlarında istatistiksel açıdan anlamlı bir farklılığa rastlanmamıştır.

Tablo 4:Suriyeli mültecilerin katıldıkları etkinlik türü, gelir düzeyleri, üyelik süresi ve eğitim düzeyleri faktörlerine bağlı olarak algıladıkları hizmet kalitesi.

\begin{tabular}{|c|c|c|c|c|c|c|c|c|c|}
\hline \multirow[t]{2}{*}{ Değiş̧kenler } & & \multirow{2}{*}{$\mathbf{n}$} & \multirow{2}{*}{$\%$} & \multicolumn{2}{|c|}{$\begin{array}{c}\text { Fiziksel Çevre } \\
\text { Kalitesi }\end{array}$} & \multicolumn{2}{|c|}{$\begin{array}{c}\text { Etkileşim } \\
\text { Kalitesi }\end{array}$} & \multicolumn{2}{|c|}{ Çıktı Kalitesi } \\
\hline & & & & $\mathrm{x}$ & ss & $\mathrm{x}$ & ss & $\mathrm{x}$ & ss \\
\hline \multirow{4}{*}{ Etkinlik Türü } & Kültürel Etkinlik & 67 & 39.6 & 4.39 & 0.83 & 4.29 & 0.51 & 4.32 & 0.54 \\
\hline & Sportif Etkinlik & 61 & 36.1 & 4.35 & 0.30 & 4.26 & 0.48 & 4.29 & 0.44 \\
\hline & Sosyal Etkinlik & 41 & 24.3 & 4.31 & 0.57 & 4.37 & 0.67 & 4.36 & 0.61 \\
\hline & & & $\mathbf{p}$ & \multicolumn{2}{|c|}{0.786} & \multicolumn{2}{|c|}{0.604} & \multicolumn{2}{|c|}{0.773} \\
\hline \multirow{5}{*}{ Gelir Düzeyi } & $0-850 \mathrm{TL}$ & 116 & 68.6 & 4.38 & 0.69 & 4.33 & 0.55 & 4.32 & 0.52 \\
\hline & $851-1500 \mathrm{TL}$ & 34 & 20.1 & 4.28 & 0.47 & 4.29 & 0.48 & 4.37 & 0.53 \\
\hline & $1501-2500 \mathrm{TL}$ & 13 & 7.7 & 4.35 & 0.25 & 4.10 & 0.57 & 4.31 & 0.47 \\
\hline & 2500 ve Üzeri & 6 & 3.6 & 4.30 & 0.27 & 4.19 & 0.60 & 4 & 0.62 \\
\hline & & & $\mathbf{p}$ & \multicolumn{2}{|c|}{0.858} & \multicolumn{2}{|c|}{0.484} & \multicolumn{2}{|c|}{0.462} \\
\hline \multirow{6}{*}{ Üyelik Süresi } & $3-6$ ay & 79 & 46.7 & 4.31 & 0.54 & 4.35 & 0.56 & 4.38 & 0.56 \\
\hline & 7-12 Аy & 48 & 28.4 & 4.44 & 0.87 & 4.24 & 0.54 & 4.26 & 0.53 \\
\hline & 1-2 Yil & 29 & 17.2 & 4.33 & 0.36 & 4.26 & 0.57 & 4.23 & 0.43 \\
\hline & 3-4 Yil & 6 & 3.60 & 4.42 & 0.28 & 4.34 & 0.25 & 4.3 & 0.45 \\
\hline & 4-5 Y1l & 7 & 4.10 & 4.34 & 0.16 & 4.29 & 0.49 & 4.31 & 0.32 \\
\hline & & & $\mathbf{p}$ & \multicolumn{2}{|c|}{0.826} & \multicolumn{2}{|c|}{0.839} & \multicolumn{2}{|c|}{0.624} \\
\hline \multirow{5}{*}{ Eğitim Düzeyi } & İlköğretim & 65 & 38.5 & 4.56 & $0.73^{\mathrm{a}}$ & 4.43 & $0.40^{\mathrm{a}}$ & 4.45 & $0.44^{\mathrm{a}}$ \\
\hline & Ortaöğretim & 53 & 31.4 & 4.23 & $0.43^{\mathrm{b}}$ & 4.22 & 0.54 & 4.31 & 0.49 \\
\hline & Üniversite & 42 & 24.9 & 4.17 & $0.59^{\mathrm{b}}$ & 4.15 & $0.71^{\mathrm{b}}$ & 4.08 & $0.62^{b}$ \\
\hline & Lisans Üstü & 9 & 5.30 & 4.50 & 0.12 & 4.49 & 0.25 & 4.47 & 0.36 \\
\hline & & & $\mathbf{p}$ & \multicolumn{2}{|c|}{$.003^{*}$} & & & \multicolumn{2}{|c|}{$.003^{*}$} \\
\hline
\end{tabular}

Tablo 4 incelendiğinde Suriyeli mültecilerin katıldıkları etkinlik türü, gelir düzeyleri ve üyelik süresi faktörlerine bağlı olarak algıladıkları hizmet kalitesi boyutlarında istatistiksel açıdan anlamlı bir farklılığga rastlanmamıştır. Eğitim düzeyleri fiziksel çevre boyutunda ilköğretim mezunu mültecilere ait ortalamalar $(4,56 \pm 0,73)$, ortaöğretim $(4,23 \pm 0,43)$ ve üniversite $(4,17 \pm 0,59)$ mezunu mültecilere nazaran yüksek bulunmuş ve bu değişimin istatistiksel açıdan da anlamlı olduğu belirlenmiştir $(\mathrm{p}<0.05)$. Etkileşim boyutunda ilköğretim mezunu mültecilere ait ortalama değer $(4,43 \pm 0,40)$ üniversite mezunu mültecilere ait ortalamalardan $(4,15 \pm 0,71)$ yüksek bulunmuş ve değişimin istatistiksel olarak anlamlı olduğu tespit edilmiştir $(\mathrm{p}<0.05)$. Çıktı kalitesi boyutunda ilköğretim mezunu mültecilere ait ortalama değer 
$(4,45 \pm 0,44)$ üniversite mezunu mültecilere ait ortalamalardan $(4,08 \pm 0,62)$ yüksek bulunmuş ve yine bu değişimin istatistiksel olarak anlamlı olduğu tespit edilmiştir $(p<0.05)$.

Tablo 5: Suriyeli mültecilerin yaş durum faktörüne bağlı olarak algıladıkları hizmet kalitesi

\begin{tabular}{|c|c|c|c|c|c|c|c|c|}
\hline \multirow[t]{2}{*}{ Yaş } & \multirow[t]{2}{*}{$\mathbf{n}$} & \multirow[t]{2}{*}{$\%$} & \multicolumn{2}{|c|}{$\begin{array}{c}\text { Fiziksel Çevre } \\
\text { Kalitesi }\end{array}$} & \multicolumn{2}{|c|}{ Etkileşim Kalitesi } & \multicolumn{2}{|c|}{ Çıktı Kalitesi } \\
\hline & & & $\mathrm{x}$ & ss & $\mathrm{x}$ & ss & $\mathrm{x}$ & ss \\
\hline 10-14 Yaş & 53 & 31.4 & 4.63 & $0.77^{\mathrm{a}}$ & 4.46 & 0.38 & 4.47 & $0.40^{\mathrm{a}}$ \\
\hline $15-20 \mathrm{Yaş}$ & 52 & 30.8 & 4.23 & $0.39^{b}$ & 4.20 & 0.59 & 4.28 & 0.50 \\
\hline $21-25 \mathrm{Yaş}$ & 40 & 23.7 & 4.21 & $0.57^{b}$ & 4.17 & 0.70 & 4.10 & $0.65^{b}$ \\
\hline $26-30 \mathrm{Yaş}$ & 12 & 7.1 & 4.25 & 0.42 & 4.40 & 0.30 & 4.40 & 0.26 \\
\hline \multirow[t]{2}{*}{ 31-35 Yaş } & 12 & 7.1 & 4.30 & 0.65 & 4.37 & 0.40 & 4.42 & 0.61 \\
\hline & & $\mathbf{p}$ & \multicolumn{2}{|c|}{$.003^{*}$} & \multicolumn{2}{|c|}{0.053} & \multicolumn{2}{|c|}{$.010^{*}$} \\
\hline
\end{tabular}

Tablo 5'te görüleceği üzere yaş faktörüne bağlı algılanan hizmet kalitesi alt boyutlarının fiziksel çevre ve çıktı kalitesinde istatistiksel anlamda farklılıklar gözlenmiştir $(\mathrm{p}<0.05)$.

\section{TARTIŞMA ve SONUÇ}

Ülkemizin sınır komşusu Suriye'de meydana gelen iç savaş neticesinde pek çok Suriyeli vatandaş ülkelerini terk etmek zorunda kalmıştır. Savaştan dolayı göç çeşitli ülkelere yapılırken en büyük göç dalgası Türkiye'ye olmuştur. Türkiye'ye sığınan Suriyelilerin bir kısmı Osmaniye ilinde yaşamlarını sürdürmeye çalışmaktadır. Devlet eliyle Suriyeli mülteciler için çeşitli imkânlar geliştirilmiş ve misafir gözüyle bakılan bu kişilerin rahat etmesi için her türlü imkân seferber edilmiştir. Kamu eliyle gerçekleştirilen ücretsiz hizmetlere Suriyeli mültecilerde katılmaktadırlar. Toplumumuzda bizlerle birlikte yaşayan Suriyeli mültecilerin sosyalleşme sürecinde aldıkları hizmetten memnun olmaları devletimizin ve milletimizin imajı için oldukça önemli olduğu düşünülmektedir; ayrıca gençlik merkezi faaliyetlerine katılan mültecilerin hizmet kalitesi algı düzeylerinin incelenmesi bu merkezde verilen hizmetin kalitesini arttırmak adına oldukça önemli olduğu söylenebilir.

Yapılan bu çalışma sonucunda elde edilen bulgulara göre Suriyeli mültecilerin cinsiyet değişkenine bağlı olarak fiziksel çevre kalitesi, etkileşim ve çıktı kalitesi alt boyutlarının tamamında kadınlara ait hizmet kalitesi algı düzeyi değerleri, erkeklere nazaran daha yüksek bulunmuş ve bu değişimin istatistiksel açıdan da anlamlı olduğu belirlenmiştir ( $\mathrm{p}<0.05)$. Ergin'in (2010) yaptığı çalışmada, kadın ve erkek katılımcıların her ikisi de algılanan hizmet kalitesine etki eden faktörlerden fiziki faktörleri en yüksek hizmet kalitesi faktörü olarak algılamaktadırlar. Katılımcıların cinsiyet dağılımları ile algılanan hizmet kalitesine etki eden faktörlerin ortalama puanları arasında istatistikî olarak anlamlı bir fark bulunmaktadır; hizmet kalitesini kadın katılımcılar, erkek katılımcılara göre daha olumlu olarak algılamaktadırlar. Yüzgenç (2010) ve Demirel (2013) tarafından yapılan çalışmalarda, hizmet kalitesi algısında cinsiyet açısından istatistiksel olarak anlamlı bir fark tespit edilmiştir. Theodorakis ve arkadaşlarının (2004) araştırma bulgularına göre, cinsiyete göre sunulan hizmet ve tesis boyutunda istatistiksel anlamda farkl1lık vardır. Erkekler tesis ve hizmetler boyutundaki 
sorulara daha yüksek puanlar vermişlerdir. Yani, kadınlar tesis ve hizmetlerden erkeklere göre daha az memnundur. Alan yazında yapılan diğer bir çalışmada cinsiyet değişkeninde, fiziksel çevre kalitesi alt boyutunda kadınların hizmet kalitesi algı düzeyinin erkeklere göre daha düşük olduğuna yönelik sonuçlar bulunmuştur (Üzüm ve ark., 2016). Aycan (2005) tarafından yapılan araştırmada gençlik merkezi üyelerinin hizmet kalitesinin alt boyutlarına yönelik algı düzeyleri cinsiyete göre anlamlı bir farklılık göstermemektedir. Araştırma bulgularındaki farklılıkların kişilerin sosyo-kültürel yapılarından kaynaklandığı düşünülmektedir.

Suriyeli mültecilerin barınma ( $\mathrm{n}=127, \%$ 75,1 evde; $\mathrm{n}=42 \%$ 27,9 misafirhanede) ve medeni durum ( $\mathrm{n}=147 \%$ 87,22 bekar; $\mathrm{n}=42, \%, 13)$ faktörlerine bağlı olarak algıladıkları hizmet kalitesi boyutlarında istatistiksel açıdan anlamlı bir farklılığa rastlanmamış; ancak hem evde barınan hem de evli olan Suriyeli mültecilerin fiziksel çevre kalitesi, etkileşim ve çıktı kalitesi alt boyutlarının tamamında hizmet algısı ortalamaları misafirhanede kalan ve bekar olanlara göre daha yüksek olduğu gözlemlenmiştir. Gencer ve arkadaşlarının (2008) yapmış oldukları çalışmada evli turistlerin çalışanlar boyutunda hizmet kalitesi algılarını bekarlara göre daha yüksek bulmuşlardır. Ergin ve ark., (2010) evli olan katılımcıların aldıkları hizmetten memnuniyet düzeylerinin bekarlara göre daha yüksek olduğu sonucuna ulaşmışlardır. "Yerel yönetimlerin sunduğu spor hizmetlerinde hizmet kalitesi” adlı çalışmalarında, medeni durum değişkenine göre çalışanlar, program ve tesis alt boyutlarında evli olan katılımcıların hizmet kalitesi alg1 düzeylerinin bekâr üyelere göre daha yüksek olduğunu tespit etmişlerdir. Araştırmacılar bu durumu, evli üyelerin sosyal anlamda, bekârlara göre daha rahat ve tecrübeli olmalarıyla, daha bilinçli ve sorumluluk sahibi oldukları için beklentilerinin de daha az olmasıyla açıklamışlardır (Üzüm ve ark., 2016). Bizde ise, güçlü aile bağlarının kurulduğu ortamlarda hayata bakışın daha pozitif olduğu düşüncesi hâkimdir.

Gençlik merkezinde Suriyeli mültecilere yönelik düzenlenen kültürel (n=67, \% 39,6 ), sportif $(n=61, \% 36,1)$ ve sosyal $(n=41, \% 24,3)$ etkinlik türü faaliyet faktörlerine bağlı olarak algıladıkları hizmet kalitesi alt boyutlarında istatistiksel açıdan anlamlı bir farklılığa rastlanmamıştır. Kültürel ve sportif etkinliklerde fiziksel çevre kalite algısı en yüksek ortalama değere sahipken, sosyal etkinliklerde etkileşim kalite algısının en yüksek ortalama değere sahip olduğu tespit edilmiştir. Kültürel ve sportif etkinliklerde fiziksel çevre kalite algısının en yüksek ortalama değere sahip olması, gençlik merkezi fiziki ortamının yeterli olduğu sonucunu düşündürmektedir. Ko \& Pastore (2004), müşterilerin hizmeti değerlendirme sürecinde, gözle görülebilir fiziksel varlıkların önemli yer tuttuğunu belirtmiş̧lerdir. Katılımcıların algılanan hizmet kalitesi faktörlerine göre puan ortalamaları incelendiğinde fiziksel faktörler en yüksek hizmet kalitesi puanına sahiptir ( Ergin, 2010).

Sosyal etkinliklerde ise etkileşim kalite ortalamasının yüksek olması, Suriyeli mülteciler ile kurulan iletişim ilişkilerinin etkili olduğunu düşündürmektedir. Howat \& Murray (2002) en yüksek hizmet performansını "personelin arkadaş canlısı olması" olarak belirtmektedirler. Ko \& Pastore (2005) çalışanların tutum, davranış ve deneyimlerinin, müşterilerin hizmet kalitesi değerlendirmeleri üzerinde etkili olduğunu belirtmişlerdir. Yıldız ve ark., (2016) fitnes merkezi üyeleri üzerine yaptıkları araştırmada ise etkileşim kalitesi bireylerin spor merkezlerinden beklentileri, tutum ve davranış değişiklikleri üzerine odaklı olduğu yönünde yorumlanmıştır. Fitness merkezlerinin üyeleriyle olumlu ilişkiler kurmaya ve bu ilişkileri 
sürdürmeye gereksinim duyduğu diğer bir ifadeyle etkileşim içerisinde olmaya ihtiyaç duydukları belirtilmiştir. Diğer bir araştırmada ise Maryam \& Kang'ın (2003) güneybatı Kore'de Cheju Adası'ndaki turistlerin hizmet kalitesi beklentilerini araştırmak için yaptıkları araştırma sonucuna göre, yerel kültürel etkinin çevre dostu tesislerden daha önemli olduğunu söylemektedirler. Kyle ve ark., (2010)'nın Yunanistan'ın kuzeyindeki iki kayak merkezi katılımcılarının sadakat ve memnuniyetinde hizmet kalitesinin etkisini araştırmak amacıyla yaptıkları araştırma bulgularına göre, hizmet kalitesiyle aralarında doğrusal ilişkiler olan psikolojik bağlılık, memnuniyet ve sadakatin katılan katılımcılarda güçlü olduğu, katılımcılar için (samimi, anlayışlı, bilgili) tesis ortamının sunulması (doğal olanaklar dahil) etkileşim, sadakat ve memnuniyet arasında pozitif bir ilişki olduğu bilgisini vermektedirler.

Gelir, satın alma davranışının üstün belirleyicisidir (Dorota, 2013). Gelir seviyesi, bir tüketicinin yaşam stili ve tutumunu etkiler ( Paul ve ark., 1996). Suriyeli mültecilerin, gelir düzeyi faktörüne bağlı olarak algıladıkları hizmet kalitesi alt boyutlarında istatistiksel açıdan anlamlı bir farklılığa rastlanmamıştır; elde edilen bu bulgu Üzüm ve ark., (2016)'nın yapmış oldukları araştırma sonucuyla örtüşmektedir. Araştırmacılar gelir düzeyi değişkeni ile hizmet kalitesi algı puanları arasında istatistiksel olarak anlamlı fark saptanmadığ belirtmişlerdir. Ardıç ve ark., (2004)'nın yaptığı araştırma bulgularına göre, vatandaşların algıladıkları genel hizmet kalitesi ile gelir düzeyleri arasında istatistiksel olarak anlamlı bir ilişki bulunmamıştır. Literatürde gelir düzeyi faktörü ile ilgili farklı bulgular da mevcuttur. Ceyhun (2006)'un yaptığı araştırma bulgularına göre, tesisin fiziksel özellikleri ile ilgili sorulardan elde edilen cevaplar ailelerin gelir düzeyleri ile karşılaştırıldığında en yüksek gelir düzeyine sahip gönüllülerden elde edilen puanların daha yüksek olduğu bulunmuştur. Yüzgenç (2010) yapmış olduğu araştırma sonuçlarına göre gençlik merkezleri üyelerinin hizmet kalitesi alt boyutları bakımından istatistiksel olarak "gelir düzeyleri" ne göre anlamlı bir fark gösterdiğini ortaya koymuştur. Araştırmamıza katılan Suriyeli mültecilerin gelir düzeylerine dair elde edilen bulgularda 169 Suriyeli mülteciden 150'sinin aylık gelir düzeyinin 0-1500 TL arasında olduğu görülmektedir. Elde edilen bu bulgu aylık asgari ücretin 1.777.50 TL (Çalışma ve Sosyal Güvenlik Bakanlığı, 2017) olduğu ülkemizde, Suriyeli mültecilerin çalışma ücret şartlarının iyileştirilmesi gerektiğini düşündürmektedir.

Suriyeli mültecilerin üyelik süresi faktörüne bağlı olarak algıladıkları hizmet kalitesi boyutlarında istatistiksel açıdan anlamlı bir farklılı̆ga rastlanmamıştır. Literatürde yapılan araştırmalar incelendiğinde tesis kullanım süresinin hizmet kalite algısı üzerindeki etkisi ile ilgili farklı sonuçlar içeren çalışmalar mevcuttur. Eraslan (2014) tesis kullanım süreleri değişse bile hizmet kalite algısında bir değişim olmadığını belirtirken, Demirel (2013) yaptığı çalışmada, sadece tesis alt boyutu bakımından üyelik süresi ve algılanan hizmet kalite algısı arasında istatistiksel olarak anlamlı bir farklılık olduğunu bildirmiştir. Kullanıcıların tesisi kullanma zamanları (yıl olarak), hizmet kalitesi için verdikleri puanlarla doğru orantılı olarak azalmaktadır (Ceyhun, 2006). Özen ve ark., (2016) ise etkinliklere katılım y1lı ve haftalık kullanım sıklı̆̆ı bağımsız değişkenleri açısından etkileşim kalitesi, çıktı kalitesi alt boyutlarında anlamlı fark olduğu tespit etmişlerdir. Yüzgenç'in (2010) yapmış olduğu araştırma sonuçlarına göre katılımcıların gençlik merkezlerine üye olma süreleri ve gençlik merkezlerini kullanım sıklıkları hizmet kalitesi algı düzeylerinde bir farklılık göstermemiştir. 
Aycan'ın (2005) yapmış olduğu çalışma sonucuna göre gençlik merkezi üyelerinin algıladıkları hizmet kalitesi düzeyleri arasında üyelik süreleri bakımından anlamlı fark vardır. Başka bir ifadeyle üyelerin hizmet kalitesi algıları, üyelik sürelerine bağlı olarak anlamlı bir şekilde değişmektedir. 1-2 yıl arası ve iki (2) yı1 üstü üyelik süresi grubuna dahil olan üyelerin algıladıkları hizmet kalitesi düzeyi, bir (1) yıldan daha az süredir üye olan gruba oranla anlamlı düzeyde yüksektir. Araştırmalardaki farkl1lıkların sebebinin, hizmeti sunan kurum ve kuruluşların hizmet sunuş biçimi, fiziksel çevre, görevlilerin tutumu vb. faktörlerden kaynaklandığını bizlere düşündürmektedir.

Suriyeli mültecilerin eğitim düzeyi durum faktörüne bağlı olarak algıladıkları hizmet kalitesi, algılanan tüm hizmet kalitesi boyutlarında istatistiksel anlamda farklılıklar göstermiştir ( $\mathrm{p}<0.05)$. Fiziksel çevre kalite algısı ortaöğretim ve üniversite mezunları arasında benzerlik gösterirken, ilköğretim mezunlarında farklılık göstermektedir. Etkileşim kalite algısı ile çıktı kalite algısı ilköğretim ve üniversite mezunları arasında farklılık göstermektedir. Aycan'ın (2005) yapmış olduğu çalışma sonucuna göre gençlik merkezi üyelerinin algıladıkları hizmet kalitesi düzeyleri arasında eğitim seviyeleri bakımından anlamlı fark bulunmuştur. Hizmet kalitesi alg1 düzeyi en yüksek ilkokul öğrencisi veya mezunu eğitim grubuna ait iken, lise öğrencisi veya mezunu eğitim grubu ise en düşük alg1 düzeyine sahip olan gruptur. Theodorakis ve ark., (2004) yaptığı araştırmaya göre, bireylerin eğitim durumlarına göre anlamlı farklılıklar vardır. En düşük eğitim seviyesine sahip müşteriler (ilköğretim), ortaöğretim ve üniversite mezunlarına göre tesis boyutundan daha memnunlardır. Ceyhun (2006)'un yaptığı araştırma bulgularına göre, öğrenim durumları bakımından lisans düzeyindeki deneklerden elde edilen puanların lise düzeyindeki deneklerden alınan puanlardan daha yüksek olduğu, istatistiksel olarak anlamlı bir farklılık olduğu tespit edilmiştir. Alexandris ve ark., (1999) yaptığı araştırma sonuçlarına göre, en düşük eğitim seviyesine sahip müşteriler (ilköğretim), ortaöğretim ve üniversite mezunlarına göre tesis boyutundan daha memnunlardır. Boz (2007)'un yaptığı araştırmada, üniversite eğitim seviyesindeki müşteriler, diğer eğitim seviyelerindeki müşterilere göre çalışanların hizmet sunum kalitesinden daha az memnun olmaktadırlar. Yani eğitim düzeyi düştükçe memnuniyet düzeyi artmaktadır. Eğitim düzeyi durum faktörüne bağlı olarak algılanan hizmet kalitesini araştırmak için alan yazında yapılan araştırma sonuçlarına göre farklı bulgular da elde edilmiştir. Yüzgenç (2010), Üzüm ve ark., (2016) yapmış oldukları araştırma sonucuna göre eğitim düzeyi değişkeni ile hizmet kalitesi algı puanları arasında istatistiksel olarak anlamlı fark saptanmamıştır. Demirel'in (2013) yapmış olduğu araştırmaya göre, eğitim seviyesi ortaokul ve üniversite olan kişiler arasında, eğitim seviyesi lise, ilkokul ve ortaokul olan üyeler arasında tesise ilişkin hizmet kalitesi puanları bakımından anlamlı bir farklılık tespit edilmemiştir. Araştırmalardaki eğitim düzeyleri ile ilgili farklı bulguların, eğitim gruplarının değişen beklentileri, çalışma alanları, evren ve örneklem farklılıkları, sosyo-demografik özellikler ile ilgili olduğunu düşündürmektedir.

Suriyeli mültecilerin yaş faktörüne bağlı algılanan hizmet kalitesi alt boyutlarının fiziksel çevre ve çıktı kalitesinde istatistiksel anlamda farklılıklar tespit edilmiştir $(\mathrm{p}<0.05)$. Fiziksel çevre kalite algısında 10-14 yaş grubu ile 15-20 ve 21-25 yaş grupları arasında anlamlı farklılıklar mevcuttur. Çıktı kalite algısında 10-14 yaş grubu ile 21-25 yaş grubu arasında 
farklılık gözlemlenmiştir. Alan yazında bulgularımızla aynı ve farklı yönlü araştırma sonuçları mevcuttur. Fiziki çevre kalitesi alt boyutu için, 19 yaş veya daha küçük olan öğrencilerin hizmet kalitesi alg1 düzeyleri, 22-23 ve 24 yaş veya daha büyük öğrencilerin hizmet kalitesi alg1 düzeylerinden daha yüksektir. Yani, yaşı küçük olan öğrencilerin, yaşı daha büyük olanlara göre hizmet kalitesi algıları daha fazladır (Eraslan, 2014). Ardıç ve ark., (2004) "Belediyelerde hizmet kalitesinin ölçülmesi" adlı çalışmalarında yaş gruplarına göre vatandaşların algıladıkları hizmet kalitesi ile memnuniyet düzeyleri arasında farklılık olduğu sonucuna ulaşmışlardır. Araştırmaya göre insanların yaşları ilerledikçe belediye hizmetlerinden memnuniyet düzeyleri artış göstermektedir. Aycan'ın (2005) yapmış olduğu çalışma sonucuna göre gençlik merkezi üyelerinin algıladıkları hizmet kalitesi düzeyleri arasında yaşları bakımından anlamlı fark vardır. 11 ve yaş grubuna dahil olan gençlik merkezi üyelerinin algıladıkları fiziksel çevre kalitesi, etkileşim kalitesi ve çıktı kalitesi düzeyi diğer yaş gruplarına oranla daha yüksek olduğu görülmektedir. Bütün boyutlarda en düşük alg1 düzeyine sahip olan üyelerin ise 15-17 yaş grubuna dâhil olanlar olduğunu belirtilmektedir. Sağlık işletmelerinde algılanan hizmet kalitesini tespit amaçlı yapılan bir araştırmada fiziksel özellikler açısından farklı yaş gruplarında bulunan kişilerin kalite skor ortalamaları arasında anlamlı düzeyde önemli bir fark olduğu tespit edilmiştir. Yaşı olan hastalar daha genç olanlara göre sunulan hizmet kalitesini daha yüksek algılamaktadır (Devebakan ve Aksaraylı, 2003). Araştırmamızdaki yaş faktörüne bağlı olarak elde ettiğimiz bulguları destekleyen benzer çalışmalar olduğu gibi, benzer olmayan sonuçları elde eden araştırmacılar da mevcuttur. Lapa ve Baştaç (2012) yılında yaptıkları çalışmada, katılımcıların hizmet kalitesi memnuniyet düzeyi puanları ile yaşları arasında istatistiksel olarak anlamlı bir fark bulamamıştır. Üzüm ve arkadaşlarının (2016) yapmış oldukları araştırma sonuçlarına göre katılımcıların yaşı ile hizmet kalitesi algı puanları arasında istatistiksel olarak anlamlı bir ilişki bulunmadığı bilgisini vermektedirler. Yıldız ve Tüfekçi’nin (2010) yılında yaptığı çalışmada yaş değişkeni ile hizmet kalitesi algı düzeyi arasında anlamlı bir ilişki bulunamamıştır. Görüldüğü gibi alan yazındaki araştırmalarda yaş ile hizmet kalitesi alg1 düzeyleri arasında farklı sonuçlara ulaşılmıştır. Böyle bir durumun ortaya çıkmasında kişilerin hizmet kalitesi beklentilerinin farklı olması, değişik yaş grupları algı düzeylerinin farklılaşması, yaşanılan yer, sosyo-ekonomik, kültürel farklılıklar ve hizmet sunuluş biçimlerinin etkili olduğu düşünülmektedir.

Dünya da; her bir dakika 24 kişi evini terk ediyor, 65,3 milyon insan mülteci olduğu ve bu sayısının hızla arttığı rapor edilmektedir. Dünya genelinde geçen yıl beş milyon kişi daha evlerini terk etmek zorunda kalmıştır, mülteci sayısının daha da artmasından endişe edilmektedir. En fazla mülteciye kaynaklık eden ülkeler sırasıyla Suriye, Afganistan ve Somali; mültecilerin yüzde 54'ü bu üç ülkeden geliyor. Türkiye barındırdığı 2,5 milyon Suriyeli sı̆̆ınmacı ile rekor sahibi. Türkiye'yi 1,6 milyon kişiyle Pakistan, 1,1 milyon kişiyle Lübnan izliyor. Mültecilerin asıl sorunu çözülemese bile yaşam kaliteleri ile ilgili düzenleme ve çalışmalara ağırlık verilmesi neredeyse bir zorunluluk ve insanlık görevi (UNCHR, 2015).

Sonuç olarak; bu çalışmada mültecilerin cinsiyet, eğitim faktörlerine bağlı olarak algılanan hizmet kalitesi alt boyutlarının tamamında istatistiksel anlamda farklılıklar gözlenmesi cinsiyet ve eğitim durumu faktörlerinin oldukça etkili olduğu kanaatini uyandırmıştır. Son 
dönemde ülkemiz, Suriyelilere yönelik kısa vadeli programlardan uzun vadeli program arayışlarına girmiştir. Bu programların en önemlisi şüphesiz eğitim politikalarıdır. Ülkemize gelen Suriyelilerin yarısından çoğunun eğitimlerini savaş nedeniyle yarıda bıraktıkları bilinmektedir. Bu nedenle gençlik merkezinde olduğu gibi, Suriyeli mültecilerin eğitimlerine yönelik program ve faaliyetlerin arttırılması için özel kuruluşlar ile sivil toplum kuruluşlarının desteğinin alınması oldukça önemlidir. Bunun için, ulusal ve uluslararası sivil toplum örgütlerinin beşeri ve finansal desteklerini arttırmaları sağlanmalıdır. Hayatlarına Avrupa ülkelerinde devam etmek isteyen mültecilerin için kültürel etkinlikler çerçevesinde yabancı dil öğretiminin fayda sağlayacağı düşüncesi de hâkimdir. Suriyeli öğrencilerin ve aileleri için rehberlik ve danışma hizmetlerinin arttırılması da önemlidir.

Mültecilerin algılanan hizmet kalitesi ortalama puan değerlerinin yüksek olması, gençlik merkezinde verilen hizmetlerden memnun oldukları ve genel anlamda gençlik merkezi kültürel, sportif ve sosyal faaliyetlerinin Suriyeli mültecilere yarar sağladığı ve sağlayacağı söylenebilir. Unutulmamalıdır ki mülteciler sadece ülkemizin değil dünyanın bir gerçeğidir; çözüm odaklı bir bakış açısı ile mültecilik bir problemden olmaktan çıkacak ve bu sorun daha çok ortak yaşam alanlarının paylaşımı ile kolayca aşılabilecektir. Ülkemizdeki Suriyeli mültecilere yönelik çalışma ve araştırmaların artması ve onlara rehber olması bakımından çalışmamız önem taşıdığı düşünülmektedir.

\section{KAYNAKLAR}

Akkaş, İ. (2015). Suriyeliler: Sınırlar ötesindeki yaşam mücadelesi. Nevşehir Hacı Bektaş Veli Üniversitesi SBE Dergisi, $5(1), 92$.

Alexandris, K., Papadopulos, P., Palialia, E., \& Vasilaidis, T. (1999). Customer satisfaction: A comparison between the public and private sport and fitness clubs in greece. European Journal of Sport Management, 6(1),40-54.

Altan, Ş., ve Atan, M., (2004). Bankacılık sektöründe toplam hizmet kalitesinin SERVQUAL analizi ile ölçümü. Gazi Üniversitesi İktisadi ve İdari Bilimler Fakültesi Dergisi, 6(1), 17-32.

Aracıoğlu, B., Ada, E., Savaşçı, İ.,Ventura, K., ve Kazancığlu, Y. (2005). Hava ve karayolu taşımacılığında algılanan hizmet kalitesinin değerlendirilmesi. İktisat-Işletme ve Finans Dergisi, 20(228), 42-53.

Ardıç, K., Yüksel, F., ve Çevik, O. (2004). Belediyelerde hizmet kalitesinin-vatandaş tatmininin ölçülmesi (Tokat Belediyesinde Bir Uygulama). Çağdaş Yerel Yönetimler Dergisi, 13(3),63-81.

Aslan, A., Kozak, M., ve Tütüncü, Ö. (2006). Seyahat acenteleri yöneticilerinin kalite algılamaları (Ege Bölgesinde Bir Araştırma). Dokuz Eylül Üniversitesi Sosyal Bilimler Enstitüsü Dergisi, 8(3),353.

Atan, M, Baş, M., ve Tolon, M., (2006). Servqual analizi ile Migros ve Gima süper marketlerinde hizmet kalitesinin ölçülmesine yönelik bir alan çalışması. Gazi Üniversitesi İktisadi ve İdari Bilimler Fakültesi Dergisi, 7(2),159-180.

Aycan, A. (2005). Gençlik merkezlerinde örgütsel etkililik ve hizmet kalitesinin değerlendirilmesi. Yayınlanmamış Doktora Tezi, Marmara Üniversitesi, Sağlık Bilimleri Enstitüsü, İstanbul.

Boz, C. (2007). Yerel yönetimlerin spor tesislerinde toplam kalite yönetimi uygulamalar (İstanbul Büyükşehir Belediyesi Örneği). Yayınlanmamış Yüksek Lisans Tezi, Marmara Üniversitesi, Sağlık Bilimleri Enstitüsü, İstanbul.

Ceyhun S. (2006). Spor işletmelerinde hizmet kalitesi. Yayınlanmamış Doktora Tezi, Gazi Üniversitesi, Sağlık Bilimleri Enstitüsü, Ankara. 
Çalışma ve Sosyal Güvenlik Bakanlığı (ÇSGB). (2017). www.csgb.gov.tr/home/contents/istatistikler/asgariucret/Erişim tarihi 12.05.2017

Demirel, H. (2013). Rekreasyonel spor/fitness programı sunan işletmelerde hizmet kalitesi. Yayınlanmamış Doktora Tezi, Gazi Üniversitesi, Sağlık Bilimleri Enstitüsü, Ankara.

Devebakan, N., ve Aksaraylı, M. (2003). Sağlık işletmelerinde algılanan hizmet kalitesinin ölçümünde servqual skorlarının kullanımı ve özel Altınordu hastanesi uygulaması. İzmir Dokuz Eylül Üniversitesi Sosyal Bilimler Enstitüsü Dergisi, $5(1), 38-54$

Dorota, R.H. (2013). Determinants of purchasing behavior. Versita, 17(1),333-345.

Dörtyol, İ.T. (2012). Ulusal Kültürün algılanan hizmet kalitesi ve algılanan müşteri değeri üzerindeki etkisi (Turizm Sektöründe Bir Araştırma). Yayınlanmamış Doktora Tezi, Cumhuriyet Üniversitesi, Sosyal Bilimler Enstitüsü, İşletme Ana Bilim Dalı, Üretim Yönetimi ve Pazarlama Bölümü, Sivas.

Eraslan, A. (2014). Üniversite yerleşkelerindeki rekreasyonel spor merkezlerinde hizmet kalitesi. Yayınlanmamış Yüksek Lisans Tezi, Gazi Üniversitesi, Sağlık Bilimleri Enstitüsü, Ankara.

Ergin, B.M. (2010). Üniversite spor merkezlerindeki algılanan hizmet kalitesinin yapısal eşitlik modeli (yem) ile incelenmesi. Yayınlanmamış Doktora Tezi, Gazi Üniversitesi, Sağlık Bilimleri Enstitüsü, Ankara.

Ergin, B.M., İmamoğlu, F.A., Tunç, T., Akpınar, S., ve Çon, M. (2010). Üniversite spor merkezlerindeki hizmet kalitesi boyutlarının algı ve önem düzeylerinin incelenmesi. Spor ve Performans Araştırmaları Dergisi, 2(1),41-49.

Gencer, R.T., Demir, C., ve Aycan, A. (2008). Kayak merkezlerindeki spor turistlerinin hizmet kalitesi algılarını etkileyen değişkenler. Ege Akademik Bakış Dergisi, 8(2),437-450.

Ghobadian, A., Speller, S., \& Matthew, J. (1994). Service quality: Concepts and models. International Journal of Quality and Reliability Management, 11( 9),43-66.

Gürel, B., ve Özel, Ç. (2013). Kamu çalışanlarının büyükşehir belediye hizmetlerinden memnuniyeti (Ankara Örneği). Hacettepe Hukuk Fakültesi Dergisi, 3(1), 65-74.

Howat, G., \& Murray, D. (2002). The role of critical incidents to complement service quality information for a sports and leisure centre. European Sport Management Quarterly, 2(1),23-46.

Kap, D. (2014). Suriyeli Mülteciler: Türkiye'nin müstakbel vatandaşları. Akademik Perspektif Dergisi, 30-35.

Karahan, K. (2006). Hizmet pazarlaması. İstanbul: Beta Yayınları.

Ko, Y.J., \& Pastore, D.L. (2004) . Current issues and conceptualizations of service quality in the recreation sport industry. West Virginia University, Sport Marketing Quarterly, 13(3), 158-166.

Ko, Y.J., \& Pastore, D.L. (2005). A hierarchical model of service quality for the recreational sport industry. Sport Marketing Quarterly, 14(2),84-97.

Kotler, P. (2002). Marketing management millenium edition. A Pearson Education Company Designing and Managing Services, Boston.

Kyle, G.T., Theodorakis, N.D., Karageorgiou, A., \& Lafazani, M. (2010). The effect of service quality on customer loyalty within the context of ski resorts. Journal of Park and Recreation Administration, 28 (1),1-15.

Lapa, T.Y., ve Baştaç, E. (2012). Antalya'da fitness merkezlerine devam eden bireylerin yaş, cinsiyet ve eğitimlerine göre bu merkezlere yönelik hizmet kalitesi değerlendirmelerinin incelenmesi. Pamukkale Journal of Sport Sciences, 3(1), 42-52.

Leisen, B., \& Vance, C. (2001). Cross-National assessment of service quality in the telecommunication industry: Evidence from the USA and Germany, Managing Service Quality, 11(5), 307-317.

Maryam, M. K. \& Kang, D. S. (2003). Service quality expectations of travellers visiting Cheju Island in Korea. Journal of Ecotourism, 2(2),114-125.

Öner-Ihlamur, S.G. (2014). Türkiye'nin Suriyeli mültecilere yönelik politikası. Ortadoğu Analiz Dergisi, 6(61), 44. 
Özen, G., Demirsoy , E., ve Üzüm, H. (2016). Gençlik hizmetleri etkinliklerine katılan bireylerin hizmet kalitesi algııı (Bolu Örneği). Journal of Bitlis Eren University Institute of Social Sciences, 5(2),133-142.

Parasuraman, A., Zeithaml, V.A., \& Berry, L.L. (1985). A conceptual model of service quality and its implications for future research. Journalof Marketing, 49(4), 41-50.

Paul, S.R., Trun K.J., \& Alan, D. (1996). House hold store brand proness: A framework. Journal of retailing, 72(2), 159-185.

Polat, E., Aycan, A., Üzüm, H., ve Polat, E. (2013). Gençlik merkezlerinde algılanan hizmet kalitesi ölçeği geçerlik ve güvenilirlik çalışması. Spor Bilimleri Dergisi Hacettepe Journal of Sport Sciences, 24(1),25-36.

Robledo, M.A. (2001). Measuring and managing service quality: Integrating Customer Expectations, 11( 1), 22-31.

Theodorakis, N., Alexandrıs, K., Rodriguez, P., \& Sarmento P.J. (2004). Measuring customer satisfaction in the context of health clubs in Portugal. International Sports Journal, 8(1),44-53.

Tjiptono, F., \& Chandra, G. (2005). Service, quality Satisfaction, Yogyakarta, Andi.

UNCHR. (2015). www.unhcr.org/576408cd7.Erişim tarihi 13.05.2017

UNCHR. (2017). www.unhcr.org/turkey/home.php?page=29. Erişim tarihi 09.05.2017

Uyguç, N. (1998). Hizmet sektöründe kalite yönetimi: Stratejik bir yaklaşım. Dokuz Eylül Yayınları, İzmir.

Üzüm H, Yeşildağ B., Karlı Ü., Ünlü H., Parlar F.M., Çokpartal C., ve Tekin N. (2016). Kamu ve özel spor merkezleri müşterilerinin hizmet kalitesi algılarının incelenmesi. Abant İzzet Baysal Üniversitesi, Sosyal Bilimler Enstitüsü Dergisi, 16( 3),167-180.

Yıldız, K., Polat, E., Sönmezoğlu, U., \& Çokpartal, C. (2016). Fitness merkezi üyelerinin algıladıkları hizmet kalitesinin belirleyicileri üzerine bir analiz. Beden Eğitimi ve Spor Bilimleri Dergisi, 10(3): 453-464.

Yıldız, S.M, ve Tüfekçi, Ö. (2010). Fitness merkezi müşterilerinin hizmet kalitesine yönelik beklenti ve algılarının değerlendirilmesi. Balıkesir Üniversitesi, Sosyal Bilimler Enstitüsü Dergisi, 14(24),1-11.

Yılmaz, İ. (2007). Hizmet kalitesinin ölçülmesi: İzmir'deki Üç, dört ve beş yıldızlı otellerde bir uygulama. Seyahat ve Otel işletmeciliği Dergisi, 4(2).

Yüzgenç, A.A. (2010). Yerel hizmetlerin sunduğu spor hizmetlerinde hizmet kalitesi. Yayınlanmamış Yüksek Lisans Tezi, Gazi Üniversitesi, Sağlık Bilimleri Enstitüsü, Ankara.

Zeithaml, V.A., Berry, L.L., \& Parasuraman, A. (1996). The behavioral consequences of service quality. Journal of Marketing, 60(2),31-46. 